\title{
The Modernist Turn in Indian Philosophy
}

\section{Prasanta S. Bandyopadhyay ${ }^{1}$}

Published online: 29 April 2019

(C) Springer Nature B.V. 2019

Nalini Bhushan and Jay Garfield's recent book, Indian Renaissance (Oxford University Press 2017) argued that Anglophonic Indian philosophy written by Indian philosophers during the period from 1857 to 1947 deserves a reappraisal. In view of their persuasive stance toward this issue, the American Philosophical Association's Asian American philosophers organized a panel to evaluate Bhushan and Garfield's work at the APA's Pacific Divisional Meetings held in San Diego in late March 2018. The panelists were Vrinda Dalmiya, Sarranindranath Tagore, and Anand Vaidya. Each provided a critical appreciation of their book. Both authors offered their responses orally in the same meetings. Due to renewed interest in their work, both editors, Purushottama Bilimoria and Sarranindranath Tagore, urged my guest editing this issue with a plan that each commentator would provide a revised version of his/her talk, and Bhushan and Garfield would subsequently write a response to each. In the meantime, Brian Hatcher graciously agreed to join as a fourth commentator to provide a historical expertise for this period of India's social and political climate. In the same issue, we are also fortunate to be able to include Purushottama Bilimoria's timely paper on 'S. Radharkrishnan: "Saving the Appearances" in East-West Academy.' The chronological ordering of his paper is, however, a bit later than Bhushan and Garfield's book. His paper has been accepted for publication after it underwent a referee's scrutiny.

I divide the introduction into three brief sections. The first section is devoted to discussing some of the salient features of the four commentaries, while the second section to the authors' rebuttal. The third and final section deals with Purushottama Bilimoria's paper.

I will begin with Dalmiya's comments. Praising their project for its ability to excavate Indian philosophy and provide a meta-narrative of this colonial period of Indian philosophy, Vrinda Dalmiya explores, along with Bhushan and Garfield, the agency and authenticity of Indianness of Indian philosophers during this vibrant period of philosophizing. She is sympathetic with the authors in their endeavor to come across a birth of a distinct kind of 'renaissance modernity' in this period. However, according to her analysis, these philosophers were torn in between being Indians and being

Prasanta S. Bandyopadhyay

psb@montana.edu

1 Department of History \& Philosophy, Montana State University, Bozeman, MT 59717, USA 
philosophers simultaneously. In her painstaking comments, Dalmiya has not hesitated to raise intriguing questions for the authors. She wonders whether their attempt to retrieve the intellectual history of this period amounts to a mere 'history of a set of micro-communities.'

Dalmiya very much appreciates their taking a closer look at Amrita Sher-Gil who was a woman artist with a mixed racial upbringing and training in Paris. Sher-Gil's background provided her with a rare freedom to move around seamlessly into different layers of global communities. She thinks that presumably Sher-Gil's ambiguous embodiment of various identities helped establish herself in a cosmopolitan world with ease. Unlike the artist who did not need a unique identity for her success, Dalmiya worries, the authors' search for Indian identity in those modern philosophers is likely to fail, as, she observes, it remains largely unsubstantiated. In this regard, she draws attention to a glaring omission in the post-independence philosophical curriculum. Indian students were not even exposed to their writings which seem odd given that they are regarded as philosophical luminaries by these authors. In the end, she remains skeptical regarding their acceptability among European philosophers even when many of them were trained in Europe.

Hatcher in his comments takes a historical approach to their book. Historians, according to him, cannot recreate the past. They merely propose hypotheses to reconstruct a segment of history, human, or otherwise. As intellectual historians of India's recent past, Bhushan and Garfield advocate the so-called concept of 'Indian Renaissance' criticized severely by both imperialists and leftists alike. Although imperialist and leftist critics stand poles apart ideologically and methodologically, they nonetheless share a remarkable affinity in understanding the emergence of the Indian against the gloomy backdrop of the eighteenth century. This was something of a fashion among old historians left and right, who wished to highlight the remarkable achievements of the nineteenth century. This way of historical thinking is currently a matter of dispute, not least because recent research has questioned whether the eighteenth century was really a period of decay or was perhaps a dynamic crucible important for the later bursting into bloom of modern Indian culture. Hatcher situates the work of Bhushan and Garfield in relation to some of these historiographical trends. He thinks their book deserves high marks for at least two reasons: they are able to (i) call attention to some of the formidable philosophers of this period, while connecting household names like Rabindranath Tagore and Gandhi to the larger context of Indian philosophy in the age of colonialism, and (ii) argue for a continuous reading of history as opposed to endorsing the once-fashionable view of the so-called Indian Renaissance as a 'rupture' with the pre-modern past.

However, Hatcher argues that Bhushan and Garfield have even so offered an overly simple answer to the question of how Indian thinkers were able to 'honor the resources of their own tradition while creatively responding to the challenge of colonial modernity.' Hatcher prefers a more complex answer and, as a result, seeks here to 'muddy the waters' a bit. He commences by looking at four key books published before the 1920's that each called attention to something momentous taking place in India at the time. He then turns to a question central to Bhusahan and Garfield's book, the operation of renaissance as a 'master trope,' and wonders if their analysis fails to recognize the major contribution made by David Kopf in this regard many decades previously. Finally, while Bhushan and Garfield draw on the wisdom of Rabindranath Tagore in 
order to celebrate the Indian Renaissance, Hatcher wonders whether they overlook Tagore's own anxieties about falling victim to rigid concepts and unexamined categories. To what extent have Bhushan and Garfield merely revisited the 'dreary sands of dead habit' as opposed to breaking new ground? In the end, Hatcher concludes that their book while exciting reverence for the Indian Renaissance may not provide the best resource for informed 'critical reflection.'

In his critique on Bhushan and Garfield's book, Sarranindranath Tagore is not so much keen on detailing some parts of their text that are liable to various interpretations. Instead, he sets himself to a constructive task of making broad critical comments on the book and its distinctive contributions to the historiography of India's intellectual history from the Sepoy Mutiny in 1857 to India's Independence in 1947. Broadly speaking, without disagreeing much with Bhushan and Garfield about their cosmopolitan account of Indian modernity, Tagore is interested in exploring the intellectual history of that period in a slightly different way. This he thinks can be achieved by borrowing the idea of "ethos" from Foucault as representing an 'attitude' of relating oneself to contemporary reality. However, unlike Bhushan and Garfield, he wants to see the tradition and modernity as being parts of 'connected histories' of two periods where the cosmopolitan spirit is 'a part of lived experience of historical agency.' This emphasis on the connected history displayed in Minds without Fear, he argues, helps recreate our past as well as transform our present in a distinctive way that builds a bridge between two parts of India's intellectual history that Bhushan and Garfield have so adroitly sketched.

Unlike the last three commentators who are more interested in social and historical aspects of Indian renaissance, which are closely tied with the book's theme, Anand Vaidya investigates it while wearing an analytic philosopher's lenses. He looks at the relationships between the self, subjectivity, and the nature of knowledge, which, among many issues, Bhushan and Garfield discuss while elaborating the works of two eminent Indian philosophers, A. C. Mukerji and K. C. Bhattacharyya. Vaidya is interested in the problem he calls 'the paradox of egocentricity', which derives from the work of A. C. Mukerji and is presented by Bhushan and Garfield. Vaidya thinks that the so-called paradox is, as it is presented, in no way comparable with Zeno's paradox because the latter is much better formulated, such that one can see the paradox immediately. He, however, thinks that there is something fascinating about the paradox of egocentricity which merits closer scrutiny. One way to appreciate his take on the paradox is to consider one formulation of the paradox and consider how one could improve on it.

1. Self-knowledge is needed for all knowledge.

2. For something to be capable of being known, it needs to be an object of knowledge.

3. But, by definition, the self cannot be an object of knowledge.

4. Therefore, self-knowledge is impossible.

5. Therefore, no one can know anything.

Vaidya questions this reconstruction of the paradox as problematic. He worries about the first premise in particular. Why should self-knowledge be necessary for all knowledge? After exploring different possible versions of self-knowledge along with the hope of getting a handle on the paradox, he ends up with a partial reconstruction of the paradox. 
P1: Knowledge has a subject-object structure.

P2: The self is an epistemic subject and never an object.

P3: For all $p$, if $S$ knows that $p$ at $t_{n}$, then there must have been a time prior to $t_{n}, t_{k}$, such that at $t_{k}, S$ can discriminate $S$ from $S^{*}$, so that $S^{\prime}$ 's knowledge can be claimed to be $\mathrm{S}$ 's as contrasted to $\mathrm{S}^{*}$ 's $\mathrm{S}$.

The core idea is that self-knowledge is necessary for all knowledge because one needs to answer the question: who is the subject that knows? Self-knowledge ties all knowledge to the individual that is the knower. Without self-knowledge we have knowledge held by subjects without any of them knowing who is the owner of the knowledge. With the help of these three premises, Vaidya contends that he is able to show the inherent inconsistency in the paradox of egocentricity, which, he thinks, is completely different from any of the skeptical problems advocated by Western philosophers. This, according to Vaidya, is what makes the paradox of egocentricity so worthy of further investigation, and which vindicates the project of Minds Without Fear as showing that Indian philosophers, from a certain period, were powerfully able to use their training in both Sanskrit and Western philosophy to engage and develop original problems worthy of our attention.

In their replies, Bhushan and Garfield acknowledge that they are intrigued to find how their critics conceptualize the Indian renaissance and as a result; their work in different planes than they have conceived it. They acknowledge that they have learned a great deal about Indian renaissance from them. Even though their critics raise different types of issues concerning their work, Bhushan and Garfield crystalize those comments to be concerned with the nature of 'particularities of colonial or postcolonial subjectivity' (email correspondence with Garfield). In short, according to them, they pertain to the nature of subjectivity in some sense or other. I will briefly summarize how they address the concerns raised by their critics.

One of Dalmiya's worries is that their account of micro-communities (Allahabad, Mysore, Calcutta, the Hindu-Muslim divide, etc.) fails to produce a cosmopolitan period. In response, they argue that each community is cosmopolitan as they look outside of India instead of looking at each other. Partially agreeing with her, they conclude that the kind of cosmopolitism they are interested is 'not only a renaissance cosmopolitanism, but also a colonial cosmopolitanism.' Unlike Dalmiya, Hatcher thinks that their problem lies in their historiography. He continues that they do not adequately appreciate the history of the Indian colonial period while ignoring the postcolonial period of India as well. In response, Bhushan and Garfield think this choice is deliberate. Their primary task is to represent the history of philosophy including the key philosophers who play the central role during the period rather than to assign the historical period that role. In contrast to Hatcher, Sarranindranath Tagore contextualizes their book in the hermeneutical tradition. But, he thinks that the book takes for granted the idea of renaissance by devoting too much time to cosmopolitism and power. Both authors, however, disagree with him. They think that there are varieties of cosmopolitism, and there is not just one linear way of construing it. However, the varieties of cosmopolitism they are interested in, they believe, are able to uncover the relationship between local and global situations. Anand interprets their book to establish a dialog between Mukerji and Bhattacharyya, on the one hand, and analytic philosophy, on the other. Bhushan and Garfield applaud his approach to 
Mukerji and Bhattacharyya's works, but, they are not interested in it because it differs from the problem identified in the book.

We now move to the last paper by Purushottama Bilimoria. In his paper, he evaluates Radhakrishnan's argument that attempts to save appearances in the Upanișhadic teachings by using Plato's doctrines. The paper offers both motivating and justificatory considerations on the part of Radhakrishnan to save 'appearances' resulting from the latter's understanding of the Upanișhadic texts. Radhakrishnan's motivating reason has to do with the failure of India's anti-realistic tradition to be the driver of modern science. The reason offered by him is that this stance on science fails to defend realism about the empirical world. Radhakrishnan's justificatory consideration stems from the fact although the world is brought about by māya , the world is not an illusion or nonexistent. However, the paper contends that his attempt to locate Śankara's 'idealism' in between being and non-being verges on a strained interpretation of Śankkara's idealism. Therefore, his account, the paper argues, is untenable.

Hope that the readers will enjoy this issue.

\section{Guest Editor.}

Acknowledgments I would like to acknowledge the help I received from Amal Banerjee, Nalini Bhushan, Gordon Brittan, Jr., Sanjit Chakrabarty, Jay Garfield, Brian Hatcher, Michelle Maskiell, Saranindranath Tagore, and Anand Vaidya for helpful comments and suggestions regarding some of the philosophical arguments including style of writing. I am also thankful to Purushottama Bilimoria for suggesting the title of this journal issue. An anonymous referee has suggested several relevant changes to it.

Publisher's Note Springer Nature remains neutral with regard to jurisdictional claims in published maps and institutional affiliations. 